doi: 10.32620/oikit.2020.90.03

УДК 656.7.022.1

М.М.Орловський, А.В.Приймак*, В.В.Войтенко*

\title{
Концепція підтримання льотної придатності повітряних суден на різних етапах життсвого циклу
}

\author{
Національний аерокосмічний університет ім. М.Є. Жуковського \\ "Харківський авіаційний інститут» \\ * Харківський національний університет Повітряних Сил ім.І.Кожедуба
}

На основі аналізу моделі льотної придатності повітряних суден та діючої на сьогодні в Україні нормативно-правової бази констатується фракт створення умов для врегулювання більшості проблем в авіаційній галузі та визначаються подальші шляхи діяльності регулюючих органів. В аспекті важливості проблеми вдосконалення системи підтримання льотної придатності повітряних суден України, визначені основні принципи і правила забезпечення і підтримання льотної придатності, а також сорормульовані вимоги до системи підтримання льотної придатності. В умовах формування і вдосконалення системи підтримання льотної придатності повітряних суден найважливішою вимогою є визначення складу і змісту ії основних концептуальних положень: принципів та методів, що підлягають реалізації на різних етапах життєвого циклу авіаційної техніки. Методи і засоби забезпечення і підтримання льотної придатності повітряних суден випливають з задач функціонування авіаційної транспортної системи і базуються на теорії надійності, імовірності і математичної статистики, теорії випадкових процесів і відновлення, дослідженні операцій і системному аналізі, теорії математичного програмування і експериментування, кібернетиці, системотехніці і ін. 3 використанням програмних засобів та обчислювальної техніки. При цьому повинні враховуватися особливості діючої вітчизняної нормативної бази, вимоги міжнародних стандартів ICAO, світовий досвід в галузі підтримання льотної придатності повітряних суден. У методологічному плані при обґрунтуванні вимог до системи забезпечення і збереження льотної придатності можуть бути використані програмно-цільові методи планування і управління. В роботі представлені основні компоненти системи підтримання льотної придатності повітряних суден. Ці компоненти відповідають за різні напрямки її функціонування у відповідності із принципами та правилами, які викладені в рамках вимог до неї. Показано глобальний вплив проблеми людського фактора на процес підтримання і збереження льотної придатності повітряних суден та на забезпечення безпеки польотів у цілому, що не можливе без докладного вивчення особливостей функціонування та відповідного удосконалення процесів технічного обслуговування та ремонту повітряних суден.

Ключові слова: повітряні судна; льотна придатність; принципи, методи, технічне обслуговування, ремонт, людський фрактор.

\section{Вступ}

Згідно із вимогами Міжнародної організації цивільної авіації (ICAO), які викладені в Додатках 1, 6 та 8, а також згідно із Керівництвом ICAO з льотної придатності [1] в Україні створена та діє національна система забезпечення, підтримання, збереження та підтвердження льотної придатності [2]. Але як будь-яка із діючих організаційних систем, незалежно від її суті та призначення, вона $є$ не ідеальною в плані забезпечення в авіаційній системі дієвих захисних механізмів від негативного впливу технічних, людських та організаційних небезпечних факторів на стан безпеки польотів (БзП).

Для України, яка є визнаною авіаційною державою із власним повним циклом (макротехнологією) створення повітряних суден (ПС) транспортної категорії, яка має виключні транзитні можливості, питання забезпечення високої ефективності власної системи підтримання льотної придатності (ЛП) є стратегічною 
задачею, від якості вирішення якої залежить привабливість галузі для іноземних авіакомпаній та інвесторів.

У розробленні науково обґрунтованих методів проектування пасажирських літаків провідна роль належить кафедрі проектування літаків і вертольотів Національного аерокосмічного університету ім. М.Є. Жуковського «XAl» [3,4].

\section{1. Концептуальні основи системи підтримання льотної придатності повітряних суден України}

В умовах фрормування і вдосконалення системи підтримання льотної придатності (ПЛП) ПС найважливішою вимогою $€$ визначення складу і змісту її основних концептуальних положень, таких як: державна політика в галузі забезпечення та підтримання ЛП ПС; основні принципи і методи забезпечення і підтримання ЛП ПС; фрактори, що визначають ЛП і сприяють її підтримці при експлуатації ПС; механізм управління процесами забезпечення і підтримання ЛП ПС.

Головним завданням при розробці системи ПЛП є визначення складу і змісту заходів, що підлягають реалізації на різних стадій життєвого циклу авіаційної техніки (АТ).

Основні принципи і правила забезпечення і ПЛП ЛА можна сформулювати наступним чином:

- ЛП закладається при проектуванні ПС із урахуванням попереднього досвіду експлуатації ПС подібного класу, вимог Замовника, державних вимог щодо безпеки та екології і підтверджується необхідним обсягом стендових і льотних випробувань, включаючи сертифікаційні випробування;

- ЛП забезпечується при серійному виготовленні ПС і контролюється на усіх етапах створення незалежною прийомкою;

- ЛП підтримується при експлуатації шляхом дотримання встановлених правил льотної експлуатації, ТО і Р ПС;

- взаємні зобов'язання Постачальника і Експлуатанта з ПЛП на увесь період експлуатації регламентуються «Типовим договором на поставку...»;

- розробка та серійне виробництво АТ здійснюються сертифікованими підприємствами авіаційної промисловості;

- кожен зразок (тип) АТ проходить сертифікацію і отримує Сертифікат типу 3 пакетом типової експлуатаційної документації;

- на кожен зразок АТ при її створенні розробляється Програма забезпечення ТО;

- кожен екземпляр АТ отримує Посвідчення про придатність до польотів (Сертифрікат льотної придатності);

- експлуатацію ПС здійснюють тільки сертифріковані Експлуатанти;

- відповідальність за ПлП ПС покладається на Експлуатанта;

- при порушенні Експлуатантом вимог до ПЛП, а також виявленні небезпечного стану ПС вводяться обмеження на його експлуатацію;

- технічне обслуговування і ремонт (ТОіР) здійснюють сертифіковані Організації $з$ TOiP;

-підготовку авіаційного персоналу здійснюють сертифіковані освітні установи;

-усі види робіт з ПЛП ПС виконує персонал, що пройшов обов'язкову атестацію;

-державний контроль за ЛП ПС на стадіях їх розробки, виробництва і експлуатації здійснюється спеціальними Уповноваженими органами.

Методи і засоби забезпечення і підтримання ЛП ПС випливають з задач фрункціонування авіаційної транспортної системи і базуються на теорії надійнос- 
ті, імовірності і математичної статистики, теорії випадкових процесів і відновлення, дослідженні операцій і системному аналізі, теорії математичного програмування і експериментування, кібернетиці, системотехніці і ін. з використанням програмних засобів та обчислювальної техніки.

У 2018 році прийнята Програма БзП в галузі цивільної авіації (ЦА) України. Згідно із ії положеннями основою забезпечення високого рівня БзП в ЦА України є впровадження в процес фрукціонування авіакомпаній сучасних технологій та методів забезпечення ЛП ПС різної категорії. У 2019 році затверджені Авіаційні правила України «Підтримання ЛП ПС та авіаційних виробів, компонентів і обладнання та схвалення організацій і персоналу, залучених до виконання цих завдань» [5], які уведені в дію з 30.06.2019 року.

Стан проблеми забезпечення БзП багато в чому визначається ефективністю діючої Системи підтримки льотної придатності ПС [6].

\section{2. Вимоги до системи підтримання льотної придатності}

В Авіаційних правилах України Частина - 21 [7] норми ЛП визначаються як частина Авіаційних правил, що містить мінімальні державні вимоги до цивільних ПС, їх двигунів і обладнання та спрямовані на забезпечення БзП.

У процесі тривалої експлуатації під впливом широкого спектра фракторів відбувається зміна характеристик конструкції, параметрів і льотних якостей повітряних суден з тенденцією до їх погіршення.

Під збереженням ЛП розуміються всі заходи, які гарантують, що в будьякий момент свого терміну служби ПС відповідають чинним вимогам і їх стан забезпечує безпечну експлуатацію.

Згадані заходи, що здійснюються під контролем відповідних повноважних органів ЦА держави - розробника і держави реєстрації передбачають:

- розробку відповідних критеріїв проектування, що забезпечує необхідну зручність проведення інспекційних оглядів і дозволяє використовувати чинні методи і способи виконання ТО;

- підготовку виробником необхідних технічних вимог, методів, правил і видів робіт, що стосуються ТО ПС та опублікування цієї інформації в такому вигляді, який може легко використовуватися Експлуатантом;

- розробку відповідної програми технічного обслуговування, прийнятною для умов експлуатації;

- надання Експлуатантом даних про дефекти та іншої суттєвої інформації, що стосується ТО і експлуатації організації, що є відповідальною за конструкцію типу, відповідно до вимог держави реєстрації;

- аналіз організацією, відповідальною за конструкцію типу, державою розробника і державою реєстрації дефектів, подій та іншої інформації, що стосується ТО і експлуатації, а також розробку і передачу інформації про рекомендовані обов'язкові дії, які здійснюються за результатами цього аналізу;

- розгляд Експлуатантом або державою реєстрації інформації, представленої організацією, що є відповідальною за конструкцію типу, або державою розробника, і прийняття необхідних дій у зв'язку із цією інформацією, звертаючи особливу увагу на дії, зазначені як «обов'язкові»;

- виконання Експлуатантом усіх обов'язкових вимог, що стосуються ПС, i, зокрема, дотримання обмежень ресурсу за умовами втоми, а також проведення будь-яких спеціальних перевірок або інспекційних оглядів, передбачених процесом сертифікації або визнаних необхідними надалі для забезпечення працезда- 
тності конструкції.

- підготовку та виконання програм додаткових інспекційних оглядів конструкції і пов'язаних із ними вимог, що стосуються старіючих ПС.

В рамках системи комплексна програма забезпечення та підтримання ЛП ПС $€$ документом, що визначає зміст, терміни виконання і виконавців робіт, спрямованих на виконання заданих вимог до ЛП ПС на стадіях їх розробки, виробництва та експлуатації. Комплексну програму розробляють з метою підвищення ефрективності і якості робіт з забезпечення і збереження ЛП ПС за допомогою: своєчасної реалізації в повному обсязі (по нормативно-технічної і методичної документації) встановленого переліку робіт із забезпечення і підтримання ЛП; поетапного контролю виконуваних робіт і оцінки відповідності встановленим вимогам значень параметрів, що характеризують ЛП і визначаються розрахунковими і експериментальними (розрахунково-експериментальними) методами; необхідного коригування та конкретизації змісту, обсягів і термінів виконання робіт з забезпечення і підтримання ЛП з урахуванням результатів робіт попередніх етапів (стадій) розробки, виробництва і експлуатації; підвищення відповідальності виконавців за виконання робіт із забезпечення та підтримання ЛП ПС;

Зміст робіт з збереження ЛП, встановлених в програмі, допускається уточнювати (доповнювати) на підставі узгоджених рішень і висновків, складених за результатами розгляду та узагальнення матеріалів етапів експлуатації.

\section{3. Основні компоненти системи підтримання льотної придатності та фак- тори, що визначають льотну придатність повітряних суден}

Виходячи зі стандартів і рекомендованої практики (SARP's) ICAO, законодавчої та нормативно-правової практики провідних авіаційних держав в проблемі державного регулювання льотної придатності ПС присутні два системних рівня, пов'язаних з різними стадіями їх життєвого циклу [6]:

- забезпечення ЛП базової конструкції (стадії проектування і виробництва);

- підтримання ЛП екземпляра повітряного судна (стадія експлуатації).

Цим рівням відповідають дві взаємозалежні системи : забезпечення і підтримання ЛП ПС. Завдання регулювання ЛП ПС в умовах конкретного держави полягає в синтезі цих систем ऽз урахуванням наявних умов і практики.

В рамках системи забезпечення ЛП відповідно до вимог SARP's ICAO [1] виділяємо три обов'язкові напрямки державного регулювання:

- сертифрікації розробника;

- сертифікації виробника;

- сертифікації типу (повітряного судна, авіадвигуна).

Ці напрямки взаємопов'язані між собою, а способи їх реалізації обумовлені: рівнем розвитку авіаційної промисловості та наявністю національних норм ЛП; обсягом авіаційно-транспортної діяльності національних та закордонних експлуатантів у державі; складом типів ПС, занесених до реєстру держави.

У зв'язку з відмінностями між державами з зазначених факторів, основною проблемою державного регулювання забезпечення ЛП є синтез задач регулювання в рамках трьох зазначених напрямків з урахуванням специфіки умов конкретної держави [1].

B межах системи ПЛП відповідно до вимог SARP's ICAO виділяємо три обов'язкові напрямки державного регулювання:

- сертифрікація експлуатантів і організацій з ТО і Р;

- сертифікація авіаційного персоналу; 
- сертифікація ЛП екземпляра ПС, яка здійснюється за умови реєстрації ПС у державі (включення до державного реєстру ПС).

На рис. 1 представлені основні компоненти системи ПЛП ПС. Ці компоненти відповідають за різні напрямки ії функціонування у відповідності із принципами та правилами, які викладені в 1 та в рамках вимог до неї ( 2 ).

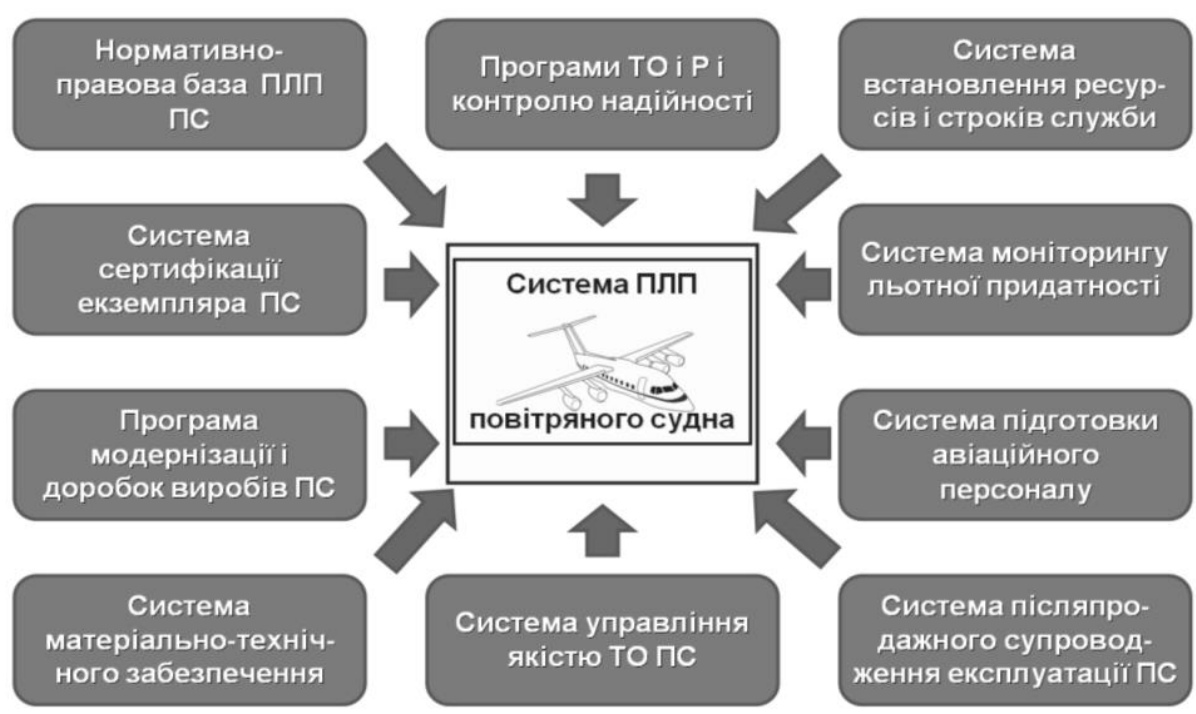

Рис. 1. Компоненти системи ПЛП ПС

3 урахуванням компонентів системи і, знову ж таки, принципів і правил та відповідних їм груп завдань з забезпечення і збереження ЛП ПС на усіх стадіях життєвого циклу, представляється можливим виділити наступні фактори (рис.2).

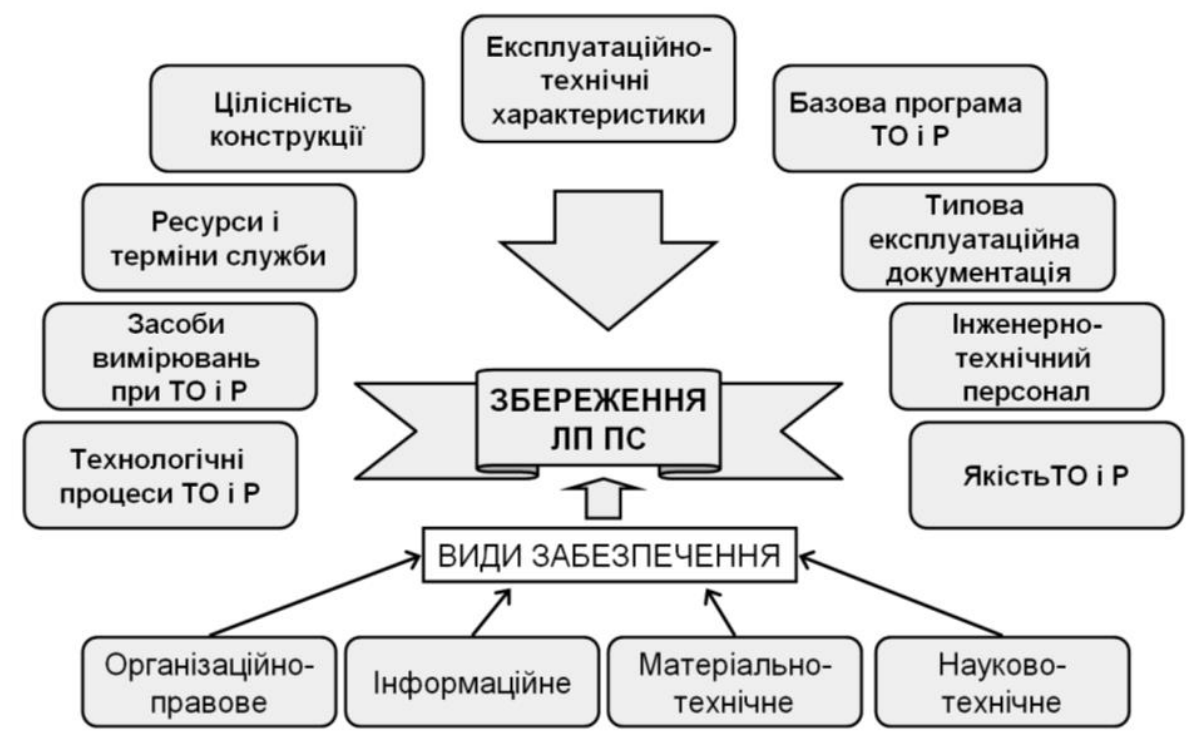

Рис. 2. Основні фрактори і види забезпечення, що визначають льотну придатність при експлуатації ПС

Крім перерахованих в табл. 1 фракторів, на ПЛГ ПС істотно впливають і інші фрактори. До їх числа відносять організаційно-правове, інформаційне, матеріально-технічне, науково-технічне забезпечення процесів ТО і Р. Ці та інші види забезпечення, що утворюють інфрраструктуру системи ТО і P, працюють не 
на окремий тип ПС, а на всі типи ПС, які експлуатуються в авіапідприємстві. Інфрраструктура створює сприятливі умови для нормального функціонування системи ПЛП кожного конкретного типу ПС. Разом із тим, зміст інфраструктури може істотно змінитися під впливом основних фракторів, що визначають ПЛГ ПС того чи іншого типу.

Таблиця 1

Задачі системи державного регулювання ЛП на різних стадіях життєвого циклу ПС

\begin{tabular}{|c|c|c|c|c|c|c|}
\hline \multirow{5}{*}{$\begin{array}{c}\text { Фактори та } \\
\text { компоненти, } \\
\text { які характе- } \\
\text { ризують рі- } \\
\text { вень лП }\end{array}$} & \multicolumn{3}{|c|}{ Системи забезпечення ЛП } & \multicolumn{3}{|c|}{ Системи підтримання ЛП } \\
\hline & \multicolumn{6}{|c|}{ Обов'язкові напрямки регулювання } \\
\hline & $\begin{array}{c}\text { Сертифі- } \\
\text { кація роз- } \\
\text { робника }\end{array}$ & $\begin{array}{l}\text { Сертифі- } \\
\text { кація ви- } \\
\text { робника }\end{array}$ & $\begin{array}{l}\text { Сертифріка- } \\
\text { ція типу }\end{array}$ & $\begin{array}{c}\text { Сертифрікація } \\
\text { експлуатантів і } \\
\text { орг. з ТОіР }\end{array}$ & $\begin{array}{c}\text { Сертифрі- } \\
\text { кація авіа } \\
\text { персоналу }\end{array}$ & $\begin{array}{c}\text { Сертифікація } \\
\text { екземпляра } \\
\text { ПС }\end{array}$ \\
\hline & \multicolumn{6}{|c|}{ Стадії життєвого циклу ПС } \\
\hline & \multicolumn{3}{|c|}{ Розробка і виробництво } & \multicolumn{3}{|c|}{ Експлуатація } \\
\hline $\begin{array}{c}\text { Експлуата- } \\
\text { ційно-технічні } \\
\text { харак- } \\
\text { теристики Пс }\end{array}$ & $\begin{array}{c}\text { Розробка і } \\
\text { забезпе- } \\
\text { чення }\end{array}$ & $\begin{array}{c}\text { Забезпе- } \\
\text { чення }\end{array}$ & $\begin{array}{c}\text { Оцінка від- } \\
\text { повідності і } \\
\text { схвалення }\end{array}$ & $\begin{array}{c}\text { Схвалення } \\
\text { програми конт- } \\
\text { ролю }\end{array}$ & $\begin{array}{c}\text { Контроль } \\
\text { знань }\end{array}$ & $\begin{array}{c}\text { Контроль і } \\
\text { оцінка відпо- } \\
\text { відності }\end{array}$ \\
\hline $\begin{array}{c}\text { Програма ТO } \\
\text { i P }\end{array}$ & \multicolumn{2}{|c|}{$\begin{array}{c}\text { Розробка і корегуван- } \\
\text { ня }\end{array}$} & $\begin{array}{c}\text { Схвалення } \\
\text { типової про- } \\
\text { грами }\end{array}$ & $\begin{array}{c}\text { Схвалення } \\
\text { програми ТОіР } \\
\text { експлуатанта }\end{array}$ & $\begin{array}{c}\text { Контроль } \\
\text { знань }\end{array}$ & $\begin{array}{c}\text { Контроль по- } \\
\text { вноти вико- } \\
\text { нання }\end{array}$ \\
\hline $\begin{array}{l}\text { Цілісність } \\
\text { конструкцій }\end{array}$ & \multicolumn{2}{|c|}{$\begin{array}{c}\text { Оцінка необхідності } \\
\text { доробок }\end{array}$} & $\begin{array}{c}\text { Схвалення } \\
\text { типової про- } \\
\text { грами } \\
\end{array}$ & $\begin{array}{c}\text { Схвалення } \\
\text { програми за- } \\
\text { безпечення }\end{array}$ & $\begin{array}{c}\text { Контроль } \\
\text { знань }\end{array}$ & $\begin{array}{c}\text { Контроль по- } \\
\text { вноти вико- } \\
\text { нання }\end{array}$ \\
\hline $\begin{array}{c}\text { Ресурси і } \\
\text { строки служ- } \\
\text { би }\end{array}$ & \multicolumn{2}{|c|}{ Встановлення } & Схвалення & $\begin{array}{l}\text { Контроль від- } \\
\text { повідності }\end{array}$ & $\begin{array}{c}\text { Контроль } \\
\text { знань }\end{array}$ & $\begin{array}{c}\text { Контроль ви- } \\
\text { конання. За- } \\
\text { твердження } \\
\text { продовження }\end{array}$ \\
\hline $\begin{array}{c}\text { Типова екс- } \\
\text { плуатаційна } \\
\text { документація }\end{array}$ & \multicolumn{2}{|c|}{$\begin{array}{c}\text { Розробка і корегуван- } \\
\text { ня }\end{array}$} & $\begin{array}{c}\text { Оцінка від- } \\
\text { повідності і } \\
\text { схвалення } \\
\end{array}$ & $\begin{array}{l}\text { Контроль від- } \\
\text { повідності }\end{array}$ & $\begin{array}{c}\text { Контроль } \\
\text { знань }\end{array}$ & $\begin{array}{l}\text { Контроль від- } \\
\text { повідності }\end{array}$ \\
\hline Якість ТО і Р & \multicolumn{2}{|c|}{ Розробка вимог } & $\begin{array}{c}\text { Схвалення } \\
\text { вимог }\end{array}$ & $\begin{array}{c}\text { Керівництво } 3 \\
\text { ТО і Р }\end{array}$ & $\begin{array}{c}\text { Контроль } \\
\text { знань }\end{array}$ & $\begin{array}{c}\text { Контроль від- } \\
\text { повідності }\end{array}$ \\
\hline $\begin{array}{c}\text { Технологічні } \\
\text { процеси ТО і } \\
\text { P }\end{array}$ & \multicolumn{2}{|c|}{$\begin{array}{c}\text { Розробка і корегуван- } \\
\text { ня }\end{array}$} & $\begin{array}{c}\text { Оцінка від- } \\
\text { повідності і } \\
\text { схвалення } \\
\end{array}$ & $\begin{array}{l}\text { Метрологічне } \\
\text { забезпечення }\end{array}$ & $\begin{array}{c}\text { Контроль } \\
\text { знань }\end{array}$ & $\begin{array}{l}\text { Контроль від- } \\
\text { повідності }\end{array}$ \\
\hline $\begin{array}{c}\text { Засоби вимі- } \\
\text { рювань при } \\
\text { ТО і Р }\end{array}$ & \multicolumn{2}{|c|}{$\begin{array}{c}\text { Розробка і корегуван- } \\
\text { ня }\end{array}$} & $\begin{array}{c}\text { Оцінка від- } \\
\text { повідності і } \\
\text { схвалення }\end{array}$ & $\begin{array}{c}\text { Контроль мет- } \\
\text { рологічного за- } \\
\text { безпечення }\end{array}$ & $\begin{array}{c}\text { Контроль } \\
\text { знань }\end{array}$ & $\begin{array}{l}\text { Контроль від- } \\
\text { повідності }\end{array}$ \\
\hline $\begin{array}{c}\text { Технічний пе- } \\
\text { рсонал }\end{array}$ & \multicolumn{2}{|c|}{ Розробка вимог } & $\begin{array}{c}\text { Критерії під- } \\
\text { готовки аві- } \\
\text { аційного } \\
\text { персоналу }\end{array}$ & $\begin{array}{c}\text { Навчання і під- } \\
\text { вищення ква- } \\
\text { ліфікації }\end{array}$ & $\begin{array}{l}\text { Видача } \\
\text { свідоцтв }\end{array}$ & $\begin{array}{l}\text { Контроль від- } \\
\text { повідності }\end{array}$ \\
\hline
\end{tabular}

Таким чином, специфріка умов побудови і результативності фрункціонування системи ПЛП ПС в конкретній державі визначається особливостями:

- основних компонентів цієї системи;

- розподілом задач регулювання між обов'язковими напрямками державного регулювання ПЛП ПС (сертифрікацією експлуатантів і підприємств з ТОiР, авіаційного персоналу і ЛП екземпляра ПС;

- розподілу потоку інформації про процес підтримання ЛП ПС в системі інформаційного забезпечення з кожного із напрямків державного регулювання ПЛП і 
між експлуатантами і Державною авіаційною адміністрацією.

\section{4. Людський фактор при технічному обслуговуванні ПС}

В умовах все зростаючих обсягів авіаперевезень в світі, підвищення інтенсивності використання ПС неминуче зростають вимоги щодо забезпечення БзП. Необхідність вирішення проблеми забезпечення БзП зумовило пошук і розробку нових методів оцінки їі рівня, фрормування теоретичних основ збереження ЛП і забезпечення БзП. При цьому слід мати на увазі, що в усіх випадках, пов'язаних із дослідженнями в даній області, присутній в явному або неявному вигляді «людський фрактор» (ЛФ) як один із найважливіших аспектів БзП [8]. .

Дані світової та вітчизняної статистики свідчать про збільшення числа авіаційних подій (АП) та інцидентів (Інц.) з причин, пов'язаних із дією людського фрактора, в тому числі і з причин неякісного ТО ПС. Так, за даними [9] кількість АП та Інц., де однією із причин були помилкові (неправильні дії) порушення авіаційного персоналу за останні декілька десятиліть суттєво збільшилась і сьогодні складає близько 70-80\%.

Стосовно ЦА України, то частка подій через ЛФ становить близько $30 \%$. Розподіл подій, що пов'язані із ЛФ, за категоріями представлена на рис. 3. Можна бачити, що ТО є другим за значенням фрактором, який впливає на стан БзП. На його долю припадає близько 16 \% усіх подій зафріксованих в Україні за останні шість років (2013-2018 рр.).

Що стосується Державної авіації України (Міністерство оборони, МВД...)[2], то згідно із статистикою за останнє десятиліття на долю помилкових дій технічного персоналу авіаційних частин та ремонтних підприємств приходиться приблизно $11 \%$ усіх інцидентів. Структура інцидентів пов'язаних із помилками технічного персоналу який задіяний у забезпеченні польотів (ЗП) ії за роками представлена на рис 4.

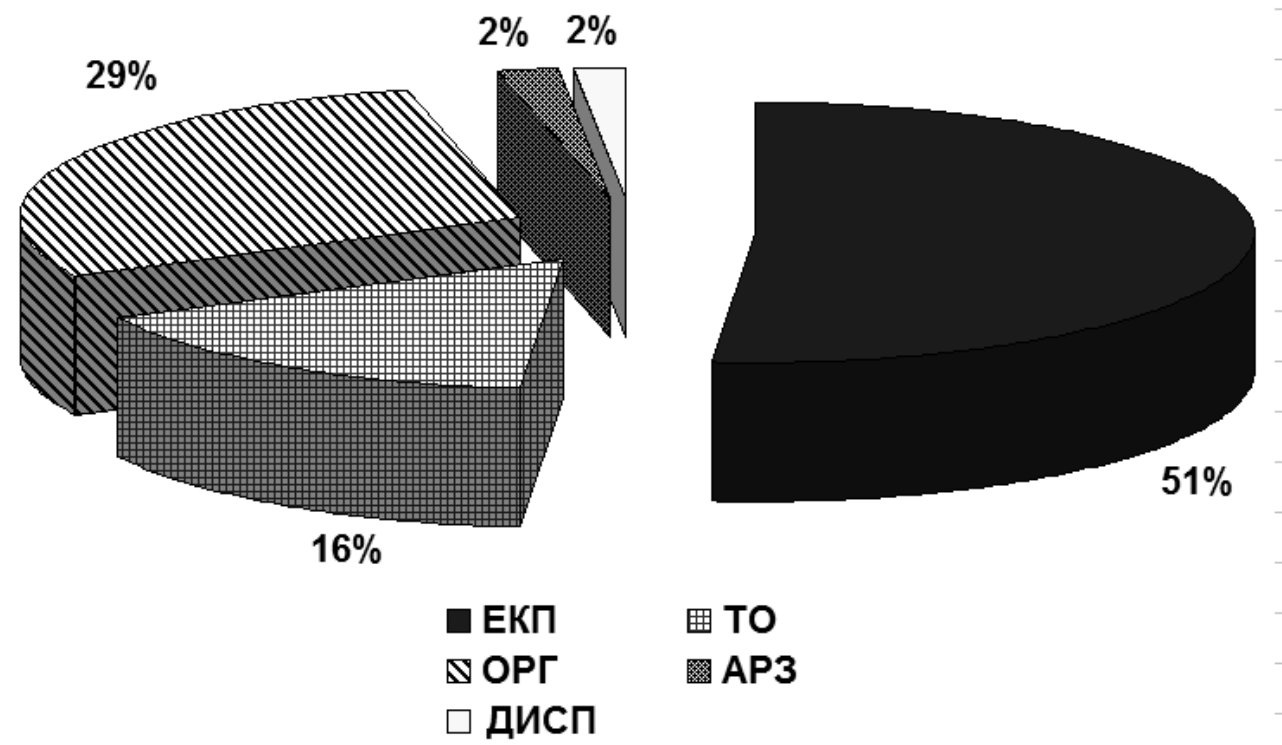

Рис. 3 - Розподіл подій, що пов'язані із ЛФ, за категоріями авіаційного персоналу (ЕКП - екіпаж, ОРГ - організаційний фрактор, АРЗ - персонал авіа-ремонтних заводів, ДИСП - персонал управління повітряним рухом, ТО - інженерно-технічний склад).

При докладному аналізі доступної статистики з БзП в Державній авіації України, в очі, в першу чергу, кидається суттєве зростання, починаючи із 2012 
року, кількості інцидентів, які пов'язані із недоліками ремонту авіаційної техніки на авіаційних ремонтних заводах.

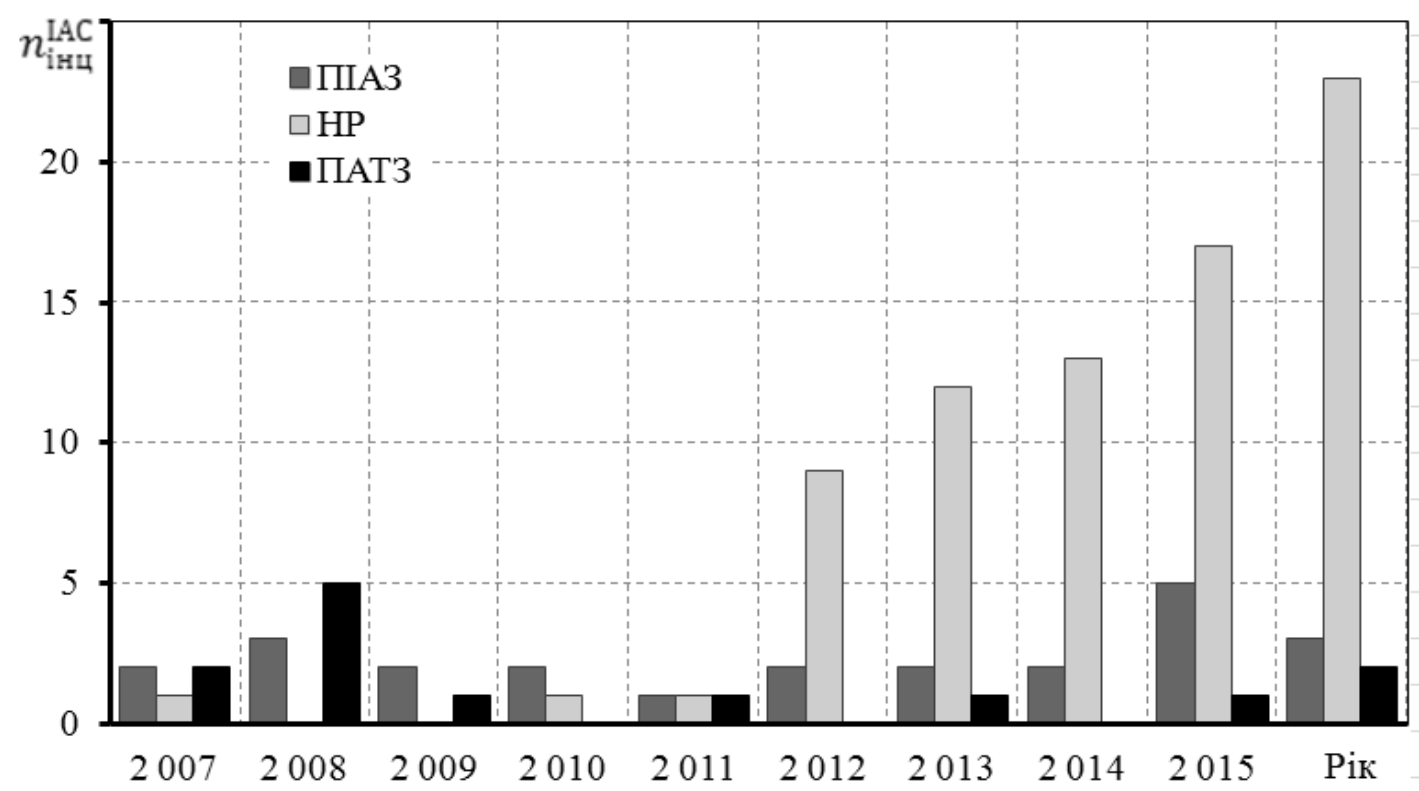

Рис. 4. - Структура інцидентів пов'язаних із помилками техперсоналу за роками:

ПІАЗ - порушення у інженерно-авіаційному забезпеченні; НР - ремонт на АРП;

ПАТЗ - рушення у аеродромно-технічному забезпеченні.

Близько 90\% усіх інцидентів, що пов'язані із НР, складають інциденти, причинами яких визначені: порушення технології ремонту та неврахування виконавцями ремонтної технологічності авіаційної техніки при виконанні ремонту. Це саме ті категорії, які максимально містять в собі фрактор людини - виконавця ремонтних робіт. На долю інших категорій приходиться лише трохи більше $10 \%$ інцидентів, переважна більшість із яких пов'язані із організаційними проблемами на виробництві.

Таким чином, беручи до уваги, що ПС спроектовано для здійснення безпечних польотів протягом тривалого часу за умови регулярного виконання на ньому великого і складного обсягу робіт з ТО авіаперсоналом, БзП істотно визначається саме «людським фрактором».

Підвищення ролі ЛФ вимагає створення та відпрацювання дієвого методологічного апарату, який би дозволив здійснити фрормалізацію проблеми та розробити методи боротьби його прояву в процесі ТО і Р.

\section{Висновки}

На основі аналізу діючої в Україні нормативно-правової бази констатується факт створення умов для врегулювання більшості проблем в авіаційній галузі. Встановлено, що ефективність їх вирішення напряму визначає стан справ в галузі забезпечення БзП тому вдосконалення діючої Системи ПЛП ПС України є пріоритетнім завданням усіх учасників авіаційного ринку.

В аспекті важливості проблеми вдосконалення Системи ПЛП ПС України визначені основні принципи і правила забезпечення і підтримання ЛП, а також сфрормульовані вимоги до системи ПЛП.

Визначено, що основною проблемою державного регулювання забезпечення ЛП є синтез задач регулювання в рамках її забезпечення на стадіях створення 
ПС та підтримання - на стадії експлуатації з урахуванням специфіки умов конкретної держави. Виходячи із цього в розділі визначено перелік необхідних компонентів ефективної системи регулювання ЛП та визначено перелік основних фракторів, що впливають на її ефективність. Встановлено мінімальний перелік видів забезпечення, що сприяють ПЛП в процесі експлуатації ПС.

Показано суттєвий вплив людського фрактору на процес підтримання та збереження ЛП ПС та на забезпечення БзП в цілому. Ї̈̈ ефективне вирішення не можливе без докладного вивчення особливостей функціонування авіаційної транспортної системи та відповідного удосконалення процесів технічного обслуговування та ремонту ПС.

\section{Список літератури}

1. Doc. ICAO №9760 AN/967 «Керівництво з льотній придатності». Видання третє. - Монреаль: ICAO, 2014. - 420 с.

2. Повітряний кодекс України. - Режим доступу: https://zakon.rada.gov.ua/ laws/show/ 3393-17

3. Гребеников, А.Г. Методология интегрированного проектирования и моделирования сборных самолетных конструкций [Текст]: монография / А.Г. Гребеников. - Харьков: Нац. аэрокосм. ун-т «Харьк. авиац. ин-т», 2006. - 532 с.

4. Балабуєв, П. В. Концепція створення сучасних реактивних регіональних пасажирських літаків [Текст] : монографрія / П.В.Балабуєв, В. О. Богуслаєв, О. Д. Донець, О. Г. Гребеніков, О. 3. Двейрін, В.М.Казуров, Є.Т. Василевський, А. М. Гуменний. - Харків : Нац. аерокосм. ун-т ім. М. Є. Жуковського «Харків. авіац. ін-т», 2020. - 254 с.

5. Авіаційні правила України «Підтримання льотної придатності повітряних суден та авіаційних виробів, компонентів і обладнання та схвалення організацій і персоналу, залучених до виконання цих завдань» [Електронний ресурс]: Затверджені наказом Державної авіаційної служби від 06.03.2019 року №286 Режим доступу: https://avia.gov.ua/wp-content/uploads/2019/08/Aviatsijni-pravilaUkrayini_Pidtrimannya-lotnoyi-pridatnosti-povitryanih-suden-ta-aviatsijnih-virobivkomponentiv-i-obladnannya-ta-shvalennya-organizatsij-i-personalu-zaluchenih-do.pdf.

6. Орловский, М. Н. Поддержание летной годности воздушных судов [Текст]: учеб. пособие / М. Н. Орловский, С. Ш. Шаабдиев. - Х.: Нац. аэрокосм. ун-т им. Н. Е. Жуковского «Харьк. авиац. ин-т», 2015. - 103 с.

7. Авіаційні правила України, Частина 21 "Сертифікація повітряних суден, пов'язаних з ними виробів, компонентів та обладнання, а також організацій розробника та виробника" АПУ-21 (Part-21): Затверджені наказом Державної авіаційної служби від 26.04.2019 № 529 - Режим доступу: https://zakon.rada. gov.ua/laws/show/z0543-19\#n16

8. Pryimak, A. Theories and models of human errors occurrence / A. Pryimak, M. Orlovskyi, Y. Tretyakov // Simulation of aircraft maintenance processes. Safety and Risk Assessment of Civil Aircraft during Operation : monograph / ed. L. Longbiao. - London : [S.n.] , 2020. - C. 81-106. - ISBN 978-1-78984-793-2.

9. Аналіз стану безпеки польотів з цивільними повітряними суднами України за результатами розслідувань авіаційних подій та інцидентів у 2018 р. - Режим доступу: https://rmd.avia.gov.ua/media/3віт_2018_aWNBfSI.pdf.

\section{References}

1. Doc. ICAO №9760 AN/967 «Kerivnytstvo po lotnii prydatnosti». Vydannia tretie. - Monreal: ISAO, 2014. - $420 \mathrm{~s}$. 
2. Povitrianyi kodeks Ukrainy. - Rezhym dostupu: https://zakon.rada.gov.ua/ laws/show/ 3393-17

3. Grebenikov, A.H. Metodolohyia yntehryrovannoho proektyrovanyia y modelyrovanyia sbornыkh samoletnыkh konstruktsyi [Tekst]: monohrafyia / A.H. Hrebenykov. - Kharkov: Nats. aэrokosm. un-t «Khark. avyats. yn-t», 2006. - 532 s.

4. Balabuiev, P. V. Kontseptsiia stvorennia suchasnykh reaktyvnykh rehionalnykh pasazhyrskykh litakiv [Tekst] : monohrafiia / P. V. Balabuiev, V. O. Bohuslaiev, O. D. Donets, O. H. Grebenikov, O. Z. Dveirin, V. M. Kazurov, Ye.T. Vasylevskyi, A. M. Humennyi. - Kharkiv : Nats. aerokosm. un-t im. M. Ye. Zhukovskoho «Kharkiv. aviats. in-t», 2020. - $254 \mathrm{~s}$.

5. Aviatsiini pravyla Ukrainy «Pidtrymannia lotnoi prydatnosti povitrianykh suden ta aviatsiinykh vyrobiv, komponentiv i obladnannia ta skhvalennia orhanizatsii i personalu, zaluchenykh do vykonannia tsykh zavdan» [Elektronnyi resurs]: Zatverdzheni nakazom Derzhavnoi aviatsiinoi sluzhby vid 06.03.2019 roku №286 Rezhym dostupu: https://avia.gov.ua/wp-content/uploads/2019/08/Aviatsijni-pravilaUkrayini_Pidtrimannya-Iotnoyi-pridatnosti-povitryanih-suden-ta-aviatsijnih-virobivkomponentiv-i-obladnannya-ta-shvalennya-organizatsij-i-personalu-zaluchenihdo.pdf.

6. Orlovskyi, M. N. Podderzhanye letnoi hodnosty vozdushnыkh sudov [Tekst]: ucheb. posobye / M. N. Orlovskyi, S. Sh. Shaabdyev. - Kh.: Nats. aэrokosm. un-t ym. N. E. Zhukovskoho «Khark. avyats. yn-t», 2015. - 103 s.

7. Aviatsiini pravyla Ukrainy, Chastyna 21 "Sertyfikatsiia povitrianykh suden, poviazanykh z nymy vyrobiv, komponentiv ta obladnannia, a takozh orhanizatsii rozrobnyka ta vyrobnyka" APU-21 (Part-21): Zatverdzheni nakazom Derzhavnoi aviatsiinoi sluzhby vid 26.04.2019 № 529 - Rezhym dostupu: https://zakon.rada.gov.ua/laws/show/z0543-19\#n16

8. Pryimak, A. Theories and models of human errors occurrence / A. Pryimak, M. Orlovskyi, Y. Tretyakov // Simulation of aircraft maintenance processes. Safety and Risk Assessment of Civil Aircraft during Operation : monograph / ed. L. Longbiao. - London : [S.n.] , 2020. - S. 81-106. - ISBN 978-1-78984-793-2.

9. Analiz stanu bezpeky polotiv z tsyvilnymy povitrianymy sudnamy Ukrainy za rezultatamy rozsliduvan aviatsiinykh podii ta intsydentiv u 2018 r. - Rezhym dostupa: https://rmd.avia.gov.ua/media/Zvit_2018_aWNBfSI.pdf.

Надійшла до редакції 12.12.2020, розглянута на редколегії 12.12.2020

\section{Concept of Continued Airworthiness of Aircraft at Different Stages of Life Cycle}

Based on the analysis of the airworthiness model of aircraft and the current legal framework in Ukraine, the fact of creating conditions for resolving most of the problems in the aviation industry is stated and further ways for the activities of regulatory bodies are determined. In the aspect of the importance of the problem of improving the system of maintaining the airworthiness of aircraft in Ukraine, the basic principles and rules for ensuring and maintaining airworthiness are determined, as well as requirements for the system for maintaining airworthiness are formulated. In the context of the formation and improvement of the aircraft continued airworthiness system, the most important requirement is to determine the composition and content of its main conceptual provisions: principles and methods to be implemented at different 
stages of the life cycle of aviation technology. Methods and means of ensuring and maintaining the airworthiness of aircraft follow from the tasks of the functioning of the aviation transport system and are based on the theory of reliability, probability and mathematical statistics, the theory of random processes and recovery, operations research and systems analysis, the theory of mathematical programming and experimentation, cybernetics, systems engineering and others with the use of software and computer technology. At the same time, the peculiarities of the current domestic regulatory framework, the requirements of ICAO international standards, world experience in maintaining the airworthiness of aircraft should be taken into account. In the methodological plan, when justifying the requirements for the system for ensuring and maintaining airworthiness, program-target planning and control methods can be used. The paper presents the main components of the aircraft airworthiness maintenance system. These components are responsible for various areas of its functioning in accordance with the principles and rules set out in the framework of the requirements for it. The global impact of the human factor problem on the process of maintaining and maintaining airworthiness of aircraft and on ensuring flight safety in general is shown, which is impossible without a detailed study of the features of the functioning and the corresponding improvement of the processes of maintenance and repair of aircraft.

Keywords: aircraft; airworthiness; principles, methods, maintenance, repair, human factor.

\section{Відомості про авторів}

Орловський Михайло Миколайович - канд. техн. наук, доцент кафедри проектування літаків та вертольотів, Національний аерокосмічний університет ім. М.Є. Жуковського «Харківський авіаційний університет», Харків, Україна. m.orlovskyi@khai.edu. ORCID 0000-0003-3529-1816.

Приймак Андрій Володимирович - канд. техн. наук, завідувач кафедри авіаційного транспорту факультету інформаційних та технічних систем інституту цивільної авіації, Харківський національний університет Повітряних Сил імені Івана Кожедуба, Харків, Україна. matrix 1971@ukr.net. ORCID 0000-0002-47072429.

Войтенко Вадим Валерійович - старший викладач кафедри конструкції літальних апаратів та двигунів інженерно-авіаційного фракультету, Харківський національний університет Повітряних Сил імені Івана Кожедуба, Харків, Україна, vadval84@ukr.net. ORCID 0000-0002-9783-3708.

\section{About the Authors}

Orlovskyi Mykhailo - Ph.D, Associate Professor, Department of Airplanes and Helicopters Design, National Aerospace University, Kharkiv, Ukraine, e-mail: m.orlovskyi@khai.edu. ORCID 0000-0003-3529-1816.

Priymak Andrey - Ph.D, Associate Professor, Head of Aviation Transport Department, Kharkov National Air Force University named by Ivan Kozhedub, Kharkov, Ukraine e-mail: matrix_1971@ukr.net. ORCID 0000-0002-4707-2429.

Voitenko Vadim - Senior Lecturer, Kharkov National Air Force University named by Ivan Kozhedub, Kharkov, Ukraine, e-mail: vadval84@ukr.net , ORCID 0000-0002-9783-3708. 